\title{
Explaining the Stunted Rise of Macroprudential Regulatory Philosophies
}

\author{
Andrew Baker
}

Reader at the School of Politics, International Studies and Philosophy, Queen's University Belfast.

In the aftermath of the financial crash of 2008, policy makers operating in international financial regulatory networks discovered macroprudential regulation (MPR), but macroprudential regulation has had a stunted or arrested development that can be explained with reference to five factors that are recounted in this article.

\section{Introduction}

In the aftermath of the financial crash of 2008, policy makers operating in international financial regulatory networks discovered macroprudential regulation (MPR) and 'systemic risk'. Indeed, the widespread recognition that financial regulation needed to become more 'macroprudential' was one of the primary regulatory reform impulses to emerge in the post-crash period. During 2009 the G20 leaders and their finance ministers and central bankers provided political support and endorsement of macroprudential regulation, highlighting the procyclicality of financial markets and the need for counter cyclical regulatory policies (G20 2009a, 2009b). The newly expanded and renovated Financial Stability Board (FSB) was given a mandate to develop macroprudential analysis and to monitor and report on macroprudential policy developments from 2009 onwards. A spate of reports produced by the European Commission, the Financial Services Authority (FSA), the G30, the Geneva Commission, the G20 and the FSB all called for the development of macroprudential regulation. Post-crash therefore, there was a rapid ideational shift in a macroprudential direction as an international consensus emerged which repeatedly endorsed the message that national authorities should try to construct macroprudential regulatory regimes and that the analytical and research machinery of various international institutions and bodies should be reoriented to support such efforts by focusing on macroprudential analysis and data collection.

The first part of this article introduces this macroprudential ideational shift and argues that macroprudential was and is a new regulatory philosophy that was substantively different from the pre-crash orthodoxy based on notions of efficient markets (Baker 2013). Its rise to prominence was only possible because it was already being promoted by a number of key individuals in international regulatory networks. These individuals or 'norm entrepreneurs' were largely well placed technocrats linked to central banks, or central bank networks and they found that the general climate of opinion in their own networks and the wider political climate was far more receptive to their ideas in the post-crash period (Baker 2013). This enabled macroprudential ideas to rise to prominence quite rapidly in the aftermath of the financial crash of 2008 , but the process of translating these ideas into concrete regulatory practice has proceeded slowly and incrementally (Baker 2014). Consequently, macroprudential regulation has had a stunted or arrested development. The rest of this article sets out to explain why this has been the case, but also points out that macroprudential regulation is here to stay and is unlikely to go away, despite some political difficulties with putting these ideas into practice. In this sense, building macroprudential regulatory regimes is likely to be long term project spanning a decade or more. 
The first reason for the stunted development of macroprudential regulation, relates to the mechanics of filling a new technocratic policy frame with functioning policy instruments. How that process proceeds depends on a process of gradual testing, experimentation, analysis, reflection and learning by an emerging cadre of macroprudential technocrats, who are by nature cautious. A second reason relates to the counter cyclical nature of macroprudential policy and the state of the international financial and banking system which remains overleveraged and the wider macroeconomy in which credit remains far from plentiful. Much macroprudential policy will only become apparent in the upswing phase of the credit cycle and is therefore time dependent. Thirdly, there remains much disagreement about how far macroprudential rationales should be extended to change existing business models and the structures of the financial system. These arguments remain to be played out. A fourth reason relates to inter-state disagreement and positions that have slowed the process of macroprudential policy formation and have given the process of developing macroprudential thinking a very uneven quality. Finally, contests over institutional turf and private sector reticence, have also slowed and diluted the process of macroprudential policy formation. These factors should not be viewed as being in opposition to one another, or competing with one another . They coexist and are interacting to produce a slow and protracted process of macroprudential regulatory regime formation, in which substantive policy content is often diluted as a consequence of the interaction of these factors.

\section{The Macroprudential Ideational Shift}

Macroprudential policy is a new ideology and a big idea. That befits what is, without question, a big crisis. There are a great many unanswered questions before this ideology can be put into practice. These questions will shape the intellectual and public policy debate over the next several decades, just as the great depression shaped the macroeconomic policy debate from the 1940s to the early 1970s (Haldane 2009-1).

Macroprudential regulation is, as the Bank of England's Director of Financial Stability, Andrew Haldane notes, a series of new, or different, ideas about how to regulate the international financial system. At its core is the notion of systemic risk. This is the idea that the build-up of risk in the financial system has a systemic dimension that goes beyond any individual institution's risk profile to include the systemic dynamics produced by the interaction of aggregate debt exposures. Containing this build-up of risk therefore, requires a macro systemic view and policy stance, with regulators mandated to check these systemic risks. This contrasts with the pre-crisis regulatory status quo that essentially involved supervisors assessing the risk models of individual financial institutions. Such an approach was referred to as 'microprudential', but it has subsequently been asserted that the focus on individual institutions was blind to the build-up of systemic risks (FSA 2009, Persaud 2009). Macroprudential regulation therefore involves system wide policies that seek to contain and constrain private sector risk taking. According to the former director of the Bank for International Settlements, Andrew Crocket, a macroprudential approach, involves a focus on the financial system as a whole, so as to limit the costs of financial distress in terms of macroeconomic output (Crockett 2000). Such a stance involves regulatory intervention into the activities of private financial markets, including placing a notional ceiling on the rate of credit expansion and activist efforts to slow asset inflation.

Four constituent concepts provide the intellectual underpinning for MPR. First, is the notion of a fallacy of composition (Borio 2011), or the idea that it is aggregate or collective systemic outcomes that matter more than individual incentives and courses of action. Second, within the macroprudential frame, financial markets are seen to be procyclical, with market prices inherently predisposed to extreme movements and volatility (Borio, Furfine \& Lowe 2001, Borio \& White 2004, White 2006, BIS 2006). Third, market participants are prone to 'herding,' or adopting behaviours close to the overall mean, as they suspend their judgment, based on an observation of and deferral to the judgment and behaviours of others. A fourth and final macroprudential concept relates to the linkages and externalities that proliferate in complex systems. As complexity and interconnections increase, evident in shadow banking and financial innovation for example, externalities proliferate, meaning that relatively small unexpected events can generate increasingly costly explosions and systemic instability and fragility (Alessandri \& Haldane 2009; Haldane 2010; Haldane \& May 2011; Taleb \& Blyth 2011). Moreover, a branch of literature points out that the excessive complexity such interconnections engender, often exceeds the capacity for human cognition, making risk incalculable (Best 2010; Blyth 2011; Haldane 2010; Turner 2011). Analysis of this kind provides a powerful rationale to move the perimeter of regulation to cover shadow banking, but also to modularise or separate financial activities, through GlassStegall type legislation, to tax and even prohibit certain financial activities and transactions, because their social 
costs in terms of lost output can exceed any economic value they generate (Haldane 2010; Tucker 2010; Turner 2011) Fallacy of composition, procyclicality and herding all have an intellectual heritage that can be traced to the work of Keynes and Minsky, both of whom advocated a much more interventionist policy stance in relation to the financial system, than the dominant orthodoxy or norm of the last thirty years (Datz 2013; Baker 2013).

Intellectually, macroprudential thinking and regulatory philosophy represents quite a movement away from the pre-crash orthodoxy. Largely this took its intellectual lead from Eugene Fama's efficient markets hypothesis (Fama 1991). From this perspective financial markets efficiently process available information, while the selfinterested rational decision making of investors, meant that financial markets tended towards equilibrium. Consequently, the principal pre-crash international financial governance challenge was the question of how to increase available information to market participants, so that they could make more informed investment decisions. This rationale and mode of thinking, informed the response to the Mexican peso and Asian financial crises of the 1990s and the launch of the international financial architectural exercises, which were intended to promote the norm of 'transparency' and increased data release by national authorities (Baker 2006; Blyth 2003). Macroprudential thinking however represents a considerable rupture with such an approach and provides a multi-faceted challenge to efficient market theory. For example, fallacy of composition challenges the notion that the rational incentives of individual actors are sufficient to generate financial stability. Procyclicality raises the prospect that financial market prices are prone to extreme swings rather than usually being correct. Herding challenges the notion that individuals have the capacity and inclination to rationally evaluate all information, while complex systems analysis indicates that complex innovative financial systems can be a cause of systemic instability and fragility rather than enhancing durability, as per the market completion hypothesis.

In this sense, the crash of 2008 acted as an event that provided a host of empirical evidence that was damaging to the efficient markets position, but provided support for a macroprudential perspective. Following the collapse of Lehmans in September 2008, the extreme downward movement in a number of interrelated asset classes was difficult to explain through an efficient markets lens. From this perspective systematic mistakes by markets (as the sum of individual rational decisions), as opposed to isolated random ones, could not happen, at least when adequate information was available, because optimising agents would drive prices into equilibrium. In contrast, the macroprudential approach that emphasised the importance of systemic thinking and highlighted the procyclical and unstable tendencies of financial markets, provided a readymade conceptual apparatus for explaining the events of autumn 2008. This conceptual approach also critiqued the dominance of the existing orthodox and its overreliance on Value at Risk (VaR) models, asserting that such an approach was a cause of the crisis, that had further 'hard wired' procyclicality into the financial system (FSA 2009). In this context, the existing orthodoxy became part of the problem that had to be replaced with new thinking. As Claudio Borio of the Bank for International Settlements (BIS), the institution that pioneered the term macroprudential in the late 1970s and began a macroprudential research programme after the Asian financial crisis, has commented, „a decade ago the term macroprudential was barely used and there was little appetite amongst policy makers and regulators to even engage with the concept, let alone strengthening macroprudential regulation" (Borio 2009: 32). Today however Borio has noted that „we are all macroprudentialists now." „This swell of support [for macroprudential regulation] could not have been anticipated even as recently as a couple of years ago. The current financial crisis has been instrumental in underpinning it" (Borio 2009: 2).

Macroprudential ideas had been, „evolving quietly in the background, known only amongst a small but growing inner circle of cognoscenti“ (Borio 2011: 1). Macroprudential ideas consequently had a prior intellectual and institutional presence, particularly at the BIS, but also amongst a select number of other economists and central bankers, which meant that many advocates of macroprudential thinking were well positioned and already had a presence in the established financial technocratic research and report writing machinery that politicians called upon to provide them with diagnoses, answers and proposals in relation to the financial crash of 2008. As Walter Mattli and Ngaire Woods have pointed out, „successful [regulatory] change is made more likely where new ideas provide a way to regulate that both offers a common ground to a coalition of entrepreneurs pressing for change and fits well with not-discredited existing institutions." (Mattli \& Woods 2009: 4-5). Macroprudential proposals had not discredited institutional and individual backers that were already linked into key policy making networks in the form of Borio's inner circle of cognoscenti. In this respect, following the financial implosion of 2008, macroprudential advocates were not starting from scratch. Individuals such as Borio and his BIS colleague William White, were already recognised and positioned within key policy networks, with a prior track record of advancing macroprudential ideas for nearly decade. The macroprudential 
perspective therefore enjoyed an advantage in terms of institutional access and a body of prior work that outlined the inadequacies of the prior efficient markets orthodoxy and was well positioned to fill the vacuum left by the apparent collapse in efficient market thinking.

The rise to prominence of macroprudential was the result of a proactive promotional strategy by a relatively small number of key macroprudential norm entrepreneurs (Finnemore \& Sikkink 1998), who engaged in a public process of diagnosis, persuasion and prescription. For example, in the UK, economists John Eatwell, Charles Goodhart and Avinash Persaud, converted Adair Turner, the new head regulator of the Financial Services Aauthority (FSA), to the macroprudential cause in briefings during the summer of 2008. Turner became one of the most forceful and eloquent advocates of the macroprudential position and began to make the macroprudential case at the meetings of the Financial Stability Forum (FSF, later FSB) in Basel ${ }^{1}$.

As the FSF prepared reports for G20 meetings, macroprudential references and thinking also began to find their way into G20 communiques, albeit somewhat cryptically under the heading 'mitigating procyclicality' with support expressed for countercyclical capital buffers, for the first time in the Horsham communiqué of 2009 (G20 2009a). William White, formerly a prominent macroprudential pioneer at the BIS had now retired, but was advising and briefing the German G20 team, and also briefing Canadian officials using the frame of MPR analysis (Balzil \& Schissel 2009). The increased access to the levers of national state policy making that macroprudential advocates enjoyed in Euro zone states, the UK and Canada, enabled the outlines of a macroprudential consensus to be built through the G20 and the FSB. A crucial G20 working group on regulation in early 2009 chaired by the Canadian central bank official Tiff Macklem and the Reserve Bank of India Governor Rakesh Mokan, produced a report calling for macroprudential regulation, and crucially Canada in the form of a leverage ratio and India in the form of some countercyclical capital requirements had both pioneered and experimented with key macroprudential instruments in the pre-crash period. By the summer of 2009 the new FSB was calling on the Basel Committee on Banking Supervision (BCBS) to commence work on countercyclical capital buffers, and it was agreed that a new Basel III agreement with a macroprudential component would be negotiated.

The significance of this post-crash macroprudential ideational shift was that policy makers' cognitive filter switched to a different setting. Policy makers are now using various combinations of the four key constituent concepts of fallacy of composition, procyclicality, herd- ing, and complex externalities to inform and guide regulatory initiatives and practice. A whole range of policy proposals could now be placed on the table and seriously discussed, that were previously out of reach. These have included: countercyclical capital requirements; dynamic loan loss provisioning; countercyclical liquidity requirements; administrative caps on aggregate lending; reserve requirements; limits on leverage in asset purchases; loan to value ratios for mortgages; loan to income ratios; minimum margins on secured lending; transaction taxes; constraints on currency mismatches; capital controls; and host country regulation (Elliot 2011). The macroprudential shift, therefore represents a potential trajectory change in financial regulation. After three decades of entrusting more and more autonomy to private actors to price and manage their own risk, that trajectory, is potentially, at least, reversed. Macroprudential concepts potentially empower regulators by providing them with the intellectual equipment to set limits to market activities, reducing the scale and restricting the scope of financial transacting (Turner, 2011). However, to date macroprudential policy development has proceeded slowly. The macroprudential regulatory philosophy has not yet translated into a substantively different approach to financial regulation. Its rise to prominence has been characterized by a stunted or arrested development. The rest of this article outlines the reasons for this stunted development.

\section{The Stunted Development of Macroprudential Policy}

The task of translating macroprudential concepts and reasoning into concrete regulatory practice and functioning macroprudential policy instruments has been proceeding slowly. Part of the reasons for this relate to the very nature of the macroprudential project itself, but also the patterns of political contestation surrounding macroprudential regulation. Five factors that have slowed and diluted macroprudential policy development are identified here.

\section{Macroprudential as a technocratic control project}

As the last section illustrated macroprudential policy was something that was largely conceived of by technocrats at central banks and the BIS. The project of constructing macroprudential regulation is something that has not only been driven and promoted by technocrats, but also involves an expansion of their role in the policy process and rests on the exercise of their expertise and informed judgement. For example, the stated objective of macroprudential policy is to moderate credit supply over the cycle, tightening policy in a boom and lowering it in a bust (Bank of England 2011). The most commonly cited macroprudential policy instrument is the counter cycli- 
cal capital buffer, a variant of which had operated in the Spanish and Indian banking systems in the pre-crash period. The idea behind a counter cyclical capital buffer is to lean against the credit cycle based on a reference path of a normalized credit to GDP ratio. Deviations above the path involve a tightening of capital requirements for private lending institutions, while deviations below that path should involve a loosening of those requirements (Haldane 2012). A functioning macroprudential policy regime therefore clearly requires regulators who have the capacity and capability to identify normalized paths of credit to GDP and deviations from that path, based on extrapolations from previous evidence and data. Further, they would also be required to reach judgements on the precise calibrations of these macroprudential policy instruments and how they should be scaled up or down to reflect particular identified phases of the credit cycle. Such a process clearly depends upon the technical capacity of regulators to reach such calculations, the data sets and data collection techniques they have to hand and some discretionary powers to reach judgments on how policy should be adjusted. One aim of the macroprudential project it has been claimed therefore is 'technocratic mastery of financial markets,' driven by a desire to open new possibilities for control of complex adaptive financial networks, through mathematized control technologies (Erturk et al. 2011).

Prior to the financial crash of 2008 there were relatively few functioning examples of macroprudential policy instruments. The Spanish example of counter cyclical capital buffers or dynamic provisioning, and Canadian use of leverage limits were outliers in developed country financial systems, although a number of Asian systems sought to constrain lending and investment activities using macroprudential type financial stability justifications, without actually naming them as such (Borio 2011). Bank of England officials have noted, 'the state of macroprudential policy resembles the state of monetary policy just after the second world war, with patchy data, incomplete theory and negligible experience, meaning that MPR will be conducted by trial and error' (Aikman, Haldane \& Nelson 2011: 1). Macroprudential policy authorities, as Haldane acknowledges will not be able to draw on decades of research and experience. Consequently, macroprudential policy is so new, and experience with it is so limited, that we have entered a very fluid phase of policy experimentation based on trial and error. The FSB/ IMF/ BIS report to G20 leaders (FSB, IMF, BIS 2011) on macroprudential policy, described systemic risk identification as a 'nascent field, that requires fundamental applied research, so as to inform the collection of analysis and data, to fill data gaps and to lead to the development of better models'. Furthermore, newly introduced tools, the report suggests, will need to be tried out in different circumstances and their performance evaluated against expectations, as macroprudential institutions are still being introduced nationally and there is no experience of the performance of these institutions to guide their design. The report is clear in stating that, 'there is no widely agreed and comprehensive theoretical framework for the optimal choice and calibration of macroprudential tools. It is still too early to provide a definite assessment of the set of macroprudential tools that will provide most useful further down the road, in part because financial innovation and change within the financial system will give rise to new risks in due course' (FSB, IMF, BIS 2011: 9-10)

Ultimately, macroprudential policy development has been informed by its character as an almost exclusively technocratic project, that initially took the form of an 'insider's coup d'etat', primarily driven forward by technocrats whose aim is to achieve technocratic mastery of financial markets, by 'rethinking' and 'mapping' the financial network (Erturk et al. 2011).

By their nature technocrats like to proceed cautiously on the basis of data sets and empirical evidence, which take time to accumulate. Consequently, the task of filling macroprudential regulators' empty policy arsenal is proceeding gradually as evidence, data and rationales are compiled and tested, as the reports above illustrate. This itself is a slow, gradual process, but it also illuminates how the character of the macroprudential project has been shaped by its technocratic character in ways which have slowed the pace of its development to date.

\section{The counter cyclical nature of macroprudential policies}

The specific countercyclical objectives of macroprudential regulation, as time variable policies means that their more interventionist and restrictive character, which require institutions to set more capital aside as macro credit supply expands, only become conspicuous at certain parts of the economic cycle. The crucial test for macroprudential policy will be how it deals with inflating credit and asset bubbles and its ability to restrain private lending, investing and transacting in such circumstances. To date de-leveraging activities and the limited supply of credit to the real economy have been used as arguments to minimise regulatory requirements. For example, this was particularly evident in the case of the Basel III agreement, - a set of international regulatory principles negotiated by central bankers in the aftermath of the financial crash to update the earlier Basel II. Bank of England officials developed a macroprudential argument to make the case for a more expansive stance on capital ratios in Basel III, arguing that capital requirements needed to be set far 
above any reasonable estimate of the losses likely to be incurred by an individual bank, because what mattered was the macro systemic stability of credit supply, not just the risk of individual failure (Turner 2011; Miles, Yang \& Marcheggiano 2011). Basel III capital ratios they claimed would therefore ideally be $15-20 \%$ of risk weighted assets, rather than the increase from 2 to 7 per cent in Basel III (Miles, Yang \& Marcheggiano 2011; Turner 2011). The objective of moving towards 15-20 per cent is however viewed as a long term one, because 'while higher equity ratios would not in the long run carry an economic penalty, a starting point of sub optimally high leverage means that higher equity ratios could slow recovery from a crisis induced recession' (Turner 2011.) This argument was accepted by more ambitious macroprudentialists such as Adair Turner and the BIS macroeconomic assessment group, whose analysis informed Basel III design. In this sense, macroprudentialists acute sensitivity to the need for countercyclical policies means that in the current circumstances they have accepted lower capital requirements in the short term, but view the task of building adequate capital requirements standards as unfinished business that will require raising requirements over the longer term as a necessary measure for long run financial stability.

\section{Disagreements on the risk weighting system and the uni- versal banking model}

The Basel III agreement also maintained the centrality of so called risk weighted assets and the internal risk models of large banks through their complex sophisticated Value at Risk models (VaR), which involve banks assessing their own risks so as to determine the bank's minimum capital requirements. Those sceptical of banks' ability to model their own financial risk, from within the macroprudential camp were not in a position to persuade either the industry or the rest of the international regulatory community to jettison a risk weight asset approach in the Basel III agreement. This fundamental component of Basel II remains unaltered therefore, with Basel III adding a mandatory capital conservation buffer of $2.5 \%$ and a discretionary countercyclical capital buffer of $2.5 \%$, during periods of high credit growth. Once the macroprudential ideational shift had taken hold by late 2009, industry representatives were in no position to prevent or oppose a countercyclical element being introduced into the Basel principles. In this sense, Basel III adds to Basel II rather than replacing it in its entirety, meaning that Basel III retains many of the features of Basel II, in a form of path dependent policy 'layering' (Baker 2014; Mahoney \& Thelen 2010).
The issue of risk weighted asset calculations recently came to public attention, when Andrew Haldane of the Bank of England criticised the Basel III agreement for producing an overly complex approach to financial regulation because of its reliance on risk weighted assets. In his 'Dog and Frisbee' speech at the most prestigious event in the annual central bank conference calendar, the Jackson Hole Conference of the Kansas City Federal Reserve (Haldane \& Madorous 2012; Masters 2012), Haldane made the argument that the shift to a highly-complex risk-weighting system for bank assets had resulted in the average amount of capital banks assigned to those assets halving over the previous 20 years, because complex rules have generated both the incentives and the means to exploit regulatory loopholes. Consequently, he asserted that simple measures of bank leverage, untainted by such complexity, were better at predicting banking failure than complex regulatory alternatives (Haldane $\&$ Madouros 2012).

Unfortunately, fellow macroprudentialist, Mark Carney, who recently become Haldane's superior at the Bank of England, may agree that regulatory policy needs to be more countercyclical and recognises the importance of leverage ratios, but does not agree with Haldane's criticisms of Basel III. In particular Carney argues that risk weighting of assets and a leverage ratio need to work in tandem, with the leverage ratio acting as an additional layer of protection from a miscalibration of risk weights, rather than replacing risk weights altogether. Using the leverage ratio as the frontline of defence, would Carney asserts, result in institutions filling the leverage ratio with the riskiest assets (Verma 2012). In this sense, two of the officials who have done most to promote, support and develop a macroprudential approach disagree on the role of risk weighted assets, with Carney's position currently winning the day, in part because of his pivotal position as chair of the FSB, that exercises some oversight of the Basel Committee on Banking Supervision that formulated the Basel III agreement. Furthermore, Carney is less the convinced about the problems of the universal banking model, and has been openly sceptical about the practicalities of the Volcker rule in the United States and its ability to achieve segmentation, or the desirability of doing so (Verma 2012). This position contrasts with Haldane's view that structural change is required, involving robust separation of retail and investment banking arms. Haldane's position in part arises from a macroprudential orientation which is sensitive to complexity and size as a spreader of risk and instability. This has been particularly evident in his collaborations with Oxford Professor of Zoology, Robert May, which compares banking systems to ecosystems and suggesting that intertwined; complex 
systems are less robust and less stable than simpler modularised systems (Haldane \& May 2011). Haldane consequently supports ring fencing, with full separation as the next logical step (Haldane 2012, 7). Haldane is quite clear that such separation is not just about reducing the size and costs of future financial shocks, but also ensuring and delivering a more stable and steady supply of credit to real economy activities.

Despite the fact that macroprudentialists such as Haldane and Carney share much common ground therefore, on two of the most crucial issues relating to the structure of the financial system, which would challenge existing business models, prominent macroprudentialists cannot agree and are unable to form a decisive coalition to push for long term structural change in the financial system. The differences between Haldane and Carney are symptomatic of this division.

\section{Inter State Disagreement}

An obvious and conspicuous interstate disagreement was evident in the Basel III negotiations. While the, US, UK and Swiss representatives argued for a much higher equity capital ratio (Hanson, Kashyap \& Stein 2011), EU regulators wanted lower requirements, fearing this would disadvantage their ailing banks. An inter-state, or inter jurisdictional contest in which actors sought to gain competitive advantage for their own financial sector therefore diluted Basel III ( Helleiner 2012; Mugge \& Stellinga 2010). National differences are also evident in relation to a number of macroprudential concepts and policy instruments. For example, US acceptance of the macroprudential approach, has according to senior international officials, always been 'half-hearted and quite partial', partly for „philosophical“ reasons, relating to a faith in markets. Ben Bernanke and many American policy makers take a minimalist view that equates with macroprudential supervision and monitoring. Consequently, there is much less emphasis in the US on procyclicality and more emphasis on Too Big to Fail (Persaud 2010; Confidential interview with official, January 2012). The United States has however displayed much more willingness to embrace leverage ratios than countercyclical capital requirements, while the opposite applies in large continental European countries, such as Germany and France, largely due to heavily leveraged large banks.

In the EU itself there have also been divisions relating to how Basel III should be translated into EU regulatory practice and statute. For example, the Fourth Capital Requirements Directive (CRDIV), which will implement Basel III in Europe raises all kind of issues and has already ignited tensions. From a single market perspective there is a case for having a single set of rules applica- ble to all. On the other hand, from a macroprudential perspective national regulators need to be able to adjust requirements for countercyclical purposes. The European Central Bank (ECB) position is that this should happen under a framework of constrained discretion, in which prior notification is given to the new European Systemic Risk Board (ESRB), to enable the ESRB to assess the spill over consequences of such a move for other countries. The French position is to go even further, and have a harmonised framework at the EU level, so that national regulators do the same thing in the same circumstances. The European Commission has also argued for a rules based approach, in which countries will have to stick to a rigid set of standards. The Dutch central bank, favours the idea of the ESRB acting as the role of mediator, as suggested by the ECB. However, both the Bank of England, and Scandinavian central banks want national macroprudential freedom and reject the idea of having to make requests to the ESRB, with the Bank of England seeking control over tools concerning leverage, liquidity, funding, lending risks and margin requirements. Currently, the CRDIV is in trialogue discussions with the Council of Ministers, European Commission and European Parliament, led by the Irish presidency, illustrating how interstate and inter institutional disagreement is impeding, or at least slowing the process of macroprudential policy development.

\section{Private sector concerns and national institutional process}

A final area of contestation relates to the fact, that while the initial acceptance of a broad macroprudential regulatory philosophy proceeded quite quickly and with relatively little opposition during 2009, the actual detailed practicalities of constructing macroprudential policy is a far more contested process. The quantitative setting of macroprudential policy instruments such as countercyclical capital requirements have implications for the day to day investment strategies and market operations of a variety of market actors. Consequently private sector actors have been far more concerned with contesting the detailed setting of policy instruments, than they have been over broad questions of macroprudential regulatory philosophyy (IIF 2011). Likewise, existing institutional actors - legislators, political parties, other agencies and bureaucracies, are taking a much closer interest in and developing stronger positions on macroprudential institutional questions, and the powers of new macroprudential policy committees, as illustrated in the case of the EU above, as a variety of actors seek to protect their own turf and standing. Furthermore, national legislative processes that enact macroprudential for new macroprudential policy committees and the scrutiny surrounding 
them, can be protracted processes. The result is a far more contested, contingent and even controversial sphere of detailed macroprudential policy development, which is likely to lead to political compromises and is liable to dilute macroprudential policy content, in substantive terms. Basel III provided some evidence of this. For example, the first scholarly account of Basel III pin points the influence of the Institute of International Finance (IIF) over the agenda and large European banks such as BNP Paribus, who had 'first mover advantage' in terms of access to the Basel Committee, enabling them to make the case that higher capital ratios would result in stagnant Euro Zone growth. Proposals on higher minimum capital ratios, the international leverage ratio, minimum liquidity ratio, and capital surcharge on systemically important institutions were all diluted in Basel III (Lall 2012: 22). Moreover, the powerful private Institute of International Finance that develops views on regulatory questions on behalf of many leading international banks has suggested that 'the science' in this area (macroprudential) is at an early stage, while using capital as an instrument of macrostabilization was 'unprecedented and untested', requiring authorities to 'exercise great caution ' (IIF 2011: 22).

\section{Conclusion}

The five factors highlighted combine to explain why the task of building functioning macroprudential has been a slow, contested and protracted process. This article has highlighted how ideational change does not automatically translate into significant regulatory change. The process of building new financial regulatory orders has historically been a long term process. After the Wall Street Crash of 1929, building the Bretton Woods order was a long run process that consisted of a four phase process, including an interregnum phase of technical refinement and experimentation (Helleiner 2010), which is probably where we are today with macroprudential policy development. In this respect, the first factor explaining the stunted development of macroprudential regulation is quite simply that such a process takes time. Two factors that are specific to macroprudential regulation have been highlighted here. The first is that macroprudential is itself a technocrat project. Technical projects take time to develop in terms of assembling data and evidence and refining what are often referred to as control technologies, while technocrats themselves tend to be cautious, thorough figures who proceed on the basis of evidence and data. A second issue is macroprudential's countercyclical objectives. This means that it responds to the economic cycle. Persistent private sector deleveraging means that there is currently more emphasis on the enabling, rather than the preventative arm of macroprudential policy in- volving efforts to encourage credit expansion. A further factor constraining macroprudential development is that key macroprudential advocates remain internally divided on important structural questions such as the emphasis given to risk weighted assets and the viability and desirability of universal banking against separated or segmented banking. Finally, political contests over macroprudential points of detail in interstate terms and private sector reticence have acted to dilute macroprudential policy in substantive terms. At the same time, institutional turf struggles are also slowing the process of implementing macroprudential frameworks. Taken together these fac-

tors have to date resulted in macroprudential regulatory

regimes that have been stunted in their development.

\section{Notes}

1. Information revealed to author in private conversations.

\section{References}

Aikman, D Haldane and Nelson, B (2011) 'Curbing the Credit Cycle', Vox, Http://voxeu.org/index.php?q=node/6231, accessed $12^{\text {th }}$ May 2011.

Alessandri, P \& Haldane, A (2009) 'Banking on the state', in Douglas Evanoff and Charles Evans eds., Proceedings of the XII Annual International Banking Conference, Federal Reserve Bank of Chicago, Chicago.

Baker, A (2006) The Group of Seven: Finance Ministries, Central Banks and Global Financial Governance, New York: Routledge.

Baker, A (2013) 'The New Political Economy of the Macroprudential Ideational Shift', New Political Economy, vol.18, no.1, pp.112-139.

Baker, A (2014) 'The Gradual Transformation? The Incremental Dynamics of Macroprudential Regulation', Regulation \& Governance, (forthcoming).

Balizil, B and Schiessl, M 2009 „The Man Nobody Wanted to Hear: Global Banking Economist Warned of Coming Crisis," Spiegel online, 07/08, available at http://www.spiegel.de/international/business/0,1518,635051,00.html

Bank of England 2011 'Instruments of Macroprudential Policy: A Discussion Paper', Available at: http:/www.bankofengland.co.uk/ publications/Documents/other/financialstability/discussionpaper111220.pdf

Best, J 2010, 'The Limits of Financial Risk Management: Or, What We Didn't Learn from the Asian Crisis', New Political Economy, vol. 15 , no. 1 , pp. $29-49$.

Borio, C 2011, 'Implementing a Macroprudential Framework: Blending Boldness and Realism', Capitalism and Society, vol. 6, no. 1, pp.1-23.

Borio, C 2009, „Implementing the Macroprudential Approach to Financial Regulation and Supervision," Banque de France, Financial Stability Review, No.13, September.

Borio, C, Furfine, C \& Lowe, P 2001, 'Procyclicality of the Financial System and Financial Stability Issues and Policy Options', BIS Papers, no.1, March, pp.1-57.

Borio, C \& White, W 2004,'Whiter Monetary and Financial Stability: The Implications for Evolving Policy Regimes', BIS working paper 147, Bank for International Settlements, Basel 
BIS 2006) $76^{\text {th }}$ Annual Report, Basel, June.

Blyth, M( 2011), 'This Time Really is Different: Europe, the Financial Crisis and 'Staying on Top' in the $21^{\text {st }}$ Century', prepared for Breznitz and Zysman (eds). "Can the Rich Countries Stay Rich?" on file with the author.

Blyth, M 2003, 'The Political Power of Financial Ideas: Transparency, Risk and Distribution in Global Finance', in Kirshner, J (eds.), Monetary Orders: Ambiguous Economics, Ubiquitous Politics, Cornell University Press: Ithaca.

Crockett, A 2000, 'Marrying the micro and macroprudential dimensions of financial stability', BIS speeches, 21 September.

Datz, G (2013) 'The Narrative of Complexity in the Crisis of Finance: Epistemological Challenge and Macroprudential Policy Response', New Political Economy, Volume 18, Number 4, 1 August 2013 , pp. 459-479.

Elliot, D (2011) 'Choosing Among Macroprudential Tools', The Brookings Institute, available at http://www.brookings.edu/ /media/ Files/rc/papers/2011/0607_macroprudential_tools_elliott/0607_ macroprudential_tools_elliott.pdf

Erturk, I, Froud, J, Leaver, A, Moran, M \&Williams, K (2011) 'Haldane's Gambit: Political Arithmetic and/ or a new metaphor', Cresc Working Paper no. 97, http://www.cresc.ac.uk/sites/default/files/ wp\%2097.pdf.

Finnemore, M \& Sikkink, K (1998) 'International Norm Dynamics and Political Change', International Organization, vol. 52, no.4, pp.887-917.

FSA (2009) 'The Turner Review', FSA: London.

FSB, IMF, BIS (2011) „Macroprudential Policy Tools and Frameworks," Progress Report to G20, 27 $7^{\text {th }}$ October.

Fama, E (1991) „Efficient Capital Markets: II,“ Journal of Finance, vol. XLVI, no. 5, pp.1575-1617.

G20 (2009a) G20 Communiqué, Meeting of Finance Ministers and Central Bank Governors, Horsham, United Kingdom, 14 March 2009.

G20 (2009b) G20 Working Group 1, 'Enhancing Sound Regulation and Strengthening Transparency', Final Report, March 25.

Haldane, A (2012) 'Towards a common financial language', Available at: http://www.bankofengland.co.uk/publications/Documents/ speeches/2012/speech552.pdf

Haldane, A (2010) 'The $\$ 100$ Billion Question', Originally presented at the Institute of Regulation \& Risk, Hong Kong, March 2010.

Haldane, A (2009) 'Small Lessons From a Big Crisis', Remarks at the Federal Reserve Bank of Chicago, $45^{\text {th }}$ Annual Conference, ,Reforming Financial Regulation," 8 May 2009.

Haldane, A \&Madouros, V (2012) 'The Dog and the Frisbee', paper presented at the Federal Reserve Bank of Kansas City's 36th economic policy symposium.

Haldane, A \& May, R (2011) 'Systemic Risk in Banking Ecosystems', Nature, no.469, pp.351-355.

Hanson, S, Kashyap, A \& Stein, J (2011) 'A Macroprudential Approach to Financial Regulation', Journal of Economic Perspectives, no. 1, pp.1-26.
Helleiner, E (2012) 'The Limits of Internationalism: The G20, the FSB and the International Regulatory Agenda', Journal of Globalization and Development, Vol. 2:2, pp.1-19.

Helleiner, E (2010) 'A Bretton Woods Moment? The 2007-08 Crisis and the Future of Global Finance', International Affairs, vol. 86, no.3, (May), pp.619-636.

IIF (2011) 'Macroprudential Oversight: An Industry Perspective', Submission to the International Authorities. Available at http://www. iif.com/regulatory/article+971.php

Lall, R (2012) „From Failure to Failure: The Politics of International Banking Regulation," Review of International Political Economy, iFirst, 31 October, http://dx.doi.org/10.1080/09692290.2011.603 669

Mahoney, J and Thelen, K (2010) 'A Theory of Gradual Institutional Change', in Mahoney J and Thelen, $\mathrm{K}$ Explaining Institutional Change: Ambiguity, Agency and Power in Historical Institutionalism, Cambridge: Cambridge University Press, pp. 1-37.

Masters, B (2012) 'Haldane Calls for Re-think of Basel III', Financial Times, 31 August.

Mattli, W \& Woods, N (2009) 'In Whose Benefit? Explaining Regulatory Change in Global Politics', in Mattli and Woods, (eds.), The Politics of Global Regulation, Princeton University Press, Princeton NJ.

Miles, D, Yang, J \& Marcheggiano, G (2011) 'Optimal Bank Capital', External MPC Unity, Discussion Paper, No.31, January 2011.

Mugge, D \& Stellinga, B (2010) 'Absent alternatives and insider interests in postcrisis financial reform', Der Moderne Staat : Zeitschrift für Public Policy, Recht und Management, vol. 3, no.2, pp. 321-338.

Persaud, A (2010) 'The Locus of Financial Regulation: Home versus host', International Affairs, vol.86, no.3, pp.637-646.

Persaud, A (2009) 'Macroprudential Regulation: Fixing Fundamental Market and Regulatory Failures', Crisis Response (Note number 6), The World Bank Group, Financial and Private Sector Development, July.

Taleb, N \& Blyth, M (2011) 'The Black Swan of Cairo: How Suppressing Volatility Makes the World Less Predictable and More Dangerous', Foreign Affairs, vol. 90, no.3, pp.33-39.

Tucker, P (2010) 'Remarks to the Institute of International Bankers, Annual Breakfast for Regulatory Dialogue', Washington DC, 11 October

Turner, A (2011) 'Reforming Finance: Are We Being Radical Enough?' Clare Distinguished Lecture in Economics and Public Policy, Cambridge, 18 February.

Verma, S (2012) 'Mark Carney: Finance's New Statesman', Euromoney, October, http://www.euromoney.com/Article/3098264/MarkCarney-Finances-new-statesmen.html.

White, W (2006) 'Procyclicality in the Financial System: Do we need a new macrofinancial stabilisation framework?' BIS Working Paper no.193, January. 